\title{
Putting Research into Practice: An Exploration of Sheffield iSchool Approaches to Connecting Research with Practice
}

\author{
Angharad Roberts, Andrew D. Madden, And \\ Sheila Corrall
}

\begin{abstract}
The relationship between research and practice in the work of members of the University of Sheffield's Information School (iSchool) was examined through a mixed-methods study carried out in two stages. Two focus groups with doctoral students and faculty members explored motivations for undertaking research, views about the impact of research, and the role of social media in its dissemination. Personal enjoyment and pursuit of knowledge for its own sake emerged as strong motivators but were also linked with expressing professional identity and contributing something useful to practice in the field. Differing stakeholder definitions of research impact were perceived as problematic, and multiple channels of communication were advocated, including judicious use of professional and social networks. A content analysis of journal articles written by iSchool faculty collected qualitative and quantitative data on the subject matter, methodology, references, and other dimensions of published output, including statements relating the research to practice. Published outputs highlighted diversity in the methods used, demonstrated collaboration with practitioners in conducting and communicating research, and identified five distinct ways of connecting research with practice. The study concludes with ten recommendations for strengthening the research-practice relationship in library and information studies.
\end{abstract}

\section{INTRODUCTION}

In library and information science (LIS) studies, research is often divided between what Busha and Harter (1980, p. 8) describe as "basic research" conducted "for its own sake" and "applied research ... aimed at solving practical problems." Powell and Connaway (2004, p. 2) also describe the interplay of both types of research. This division between basic 
and applied research is sometimes seen as reflecting the distinction between research conducted by academic faculty, which tends to be seen as more theoretical or basic research, and that conducted in practice settings, which tends to take the form of applied research (McClure, 1989, pp. 282-283). However, Goulding and Matthews (2002, p. 64) note that academicians may undertake either type of research, motivated by an interest to discover "something new-a process perhaps more applicable to basic, theoretical research-or in solving a problem—an outcome more relevant to this discussion of practical, applied research."

There has been much discussion of what has sometimes been described as the research-practice gap in LIS studies (Luo, 2011; McKechnie, Julien, \& Oliphant, 2008). McClure (1989, p. 284) describes researchers and library managers as exemplifying "two cultures." Haddow and Klobas (2004) describe eleven dimensions of this research-practice gap. However, McKee (2007, p. 26) suggests that the idea of "two communities" in LIS research should be expanded to include consideration of policy maker perspectives, alongside those of researchers and practitioners, reinforcing the message of Goulding and Usherwood (2003, p. 138), who emphasize "the need to ensure that research is disseminated to the relevant community so that it can be acted upon," and Usherwood (2002, p. 11), who argues, "It is important that key professional staff and policy makers recognize the value of research as a contributor to, and demonstrator of, library performance."

Although a number of studies have explored both researcher and practitioner perspectives on specific aspects of this gap, such as interlibrary loan trends or the use of, or preference for, specific types of journals (Klobas \& Clyde, 2010; Montanelli \& Mak, 1988; Schlögl \& Stock, 2008), other studies have focused in much more depth on practitioner perspectives alone (Ali, 1985; Clapton, 2010; Luo, 2011; Powell, Baker, \& Mika, 2002; Turner, 2002). There appear to be relatively few studies exploring LIS researcher perceptions of the research-practice divide.

The University of Sheffield Information School (iSchool) has been involved in encouraging connections between research and practice since its inception in 1963 as the Postgraduate School of Librarianship. Goulding and Usherwood (2003, p. 138) emphasize "the importance of the links between teaching, research and practice" and describe how faculty members at Sheffield maintain awareness of current practice through involvement in professional associations and how they incorporate research into the teaching curriculum, by drawing on research by departmental members and external researchers, involving research staff and visiting speakers in classes, and engaging students in inquiry-based learning and practical research projects. The Sheffield master's curriculum includes a research methods course and a dissertation, with the expectation that graduates will be able to apply the methodologies introduced to their own research, including the ability "to write an accurate, lucid research report 
and disseminate findings appropriately to different audiences," and that "they will be in an informed position to evaluate the research reports that will pass across their desks when they take up a professional post" (Goulding \& Usherwood, 2003, p. 138).

The present study explores some of the current dimensions of the relationship between research and practice in LIS through an analysis of focus group discussions with researchers in the Sheffield iSchool community and content analysis of articles published by faculty. The iSchool has been involved in debates about the relationship between research and practice for some time: Haddow and Klobas (2004, p. 36) describe a study from the late 1980s examining the impact of research conducted at what was then the Department of Information Studies, and Usherwood (2002), reporting on social audit studies conducted at Sheffield in the 1990s, discusses the use of qualitative research data to demonstrate the value and impact of public libraries and also suggests strategies for improving the dissemination of library research, including a website to update practitioners, academicians, and policy makers on research being carried out in the field, including "the 'hidden research' that is undertaken as part of day-to-day management of libraries" (Goulding \& Usherwood, 2003, p. 138). In addition to educating new professionals, the iSchool provides continuing professional development opportunities to practitioners in the field, with a strong emphasis on conducting research (Corrall, 2010, pp. 577-578). The iSchool community, therefore, seems a suitable context in which to explore researcher and faculty perceptions of relating research to practice.

The study aimed to address three specific research questions:

- What motivates iSchool researchers to conduct research?

- What opinions do iSchool researchers have about the dissemination of research findings and the impact of those findings on practice?

- How is the relationship between research and practice reflected in the publications of iSchool researchers?

The next section is a review of literature related to the relationship between research and practice in LIS, concentrating on reflective and evidencebased practice, the role of LIS faculty, and issues in the dissemination of research. Subsequent sections provide an account of the methodology used in the study, presentation of the results from the two stages of the research (focus groups and content analysis), discussion of the findings, and the conclusion and recommendations.

\section{Literature ReView}

\section{Reflective and Evidence-Based Practice}

The debate about the relationship between LIS research and practice is increasingly informed by perspectives offered by reflective practice and 
evidence-based approaches. McClure (1989, pp. 288-289) relates his discussion of ways of improving the utility of research for practice to what was then the relatively new idea of reflective practice, suggesting that this approach might provide more realistic and nuanced ways of understanding practice than some of the more "rational" frameworks applied by researchers. Turner (2002, pp. 237, 239) also discusses the role of research undertaken by practitioners in facilitating reflective practice.

The more recent emergence of evidence-based approaches to library and information practice-traced to the late 1990s by Koufogiannakis, Slater, and Crumley (2004, p. 227) —is also seen as combining with trends in the development of reflective practice to prompt greater practitioner engagement with research (Booth, 2003, pp.15-16; Goulding and Matthews, 2002, p. 64). Evidence-based practice offers a way of foregrounding the importance of research to practice (Booth, 2003, p. 4; Haddow, 2010, p. 33), as well as encouraging specific projects to build research capacity in a practice setting, such as the cross-sectoral work described by Childs and Dobbins (2003) involving libraries in the UK National Health Service, health libraries in higher education, and a research institute in an informatics school.

Kloda, Koufogiannakis, and Mallan (2011) describe practitioner perspectives on the value of research for evidence-based practice, as shown by 101 published evidence summaries of individual research studies. Although issues relating to the validity and reliability of the studies are frequently cited as weaknesses, the applicability of the research findings to practice settings seems generally to be viewed positively.

\section{The Role of Library and Information Studies Faculty}

A number of potential roles are suggested for LIS researchers and faculty members in addressing the research-practice gap. Sometimes, the perceptions are contradictory: Goulding and Matthews (2002, p. 65) note trends toward increasing partnerships between researchers and practitioners, while Lang (2002, p. 875) suggests not only that it is "rare for academics and practitioners to work together" but also that it is LIS researchers and faculty members who have the greatest to lose by this lack of links to practitioners.

Swigger (1985, p. 109) speculates that "perhaps the true function of library science faculty is not to produce voluminous research but to instruct practitioners in how to do their own research," emphasizing the role of LIS departments in equipping future professionals with the tools to conduct and evaluate research appropriately in their own practice settings. McClure (1989, p. 290) notes a tension between the education given to librarians and that provided for researchers, suggesting that, at that time, it was "geared to increase conflict." Robbins (1990, p. 128) also includes improving practitioner research training as one of five recommen- 
dations for increasing the use of research in practice. Lang (2002, p. 872) suggests that including research evidence in teaching for postgraduate professional qualifications may provide a potential way of engaging practitioners in research.

Specific aspects of LIS courses have been identified as providing opportunities to encourage engagement with research by future practitioners, including ensuring that there are research elements to LIS students' work placements (Berg, Hoffman, \& Dawson, 2009), and evaluating current practitioners' perceptions of the value of research methods courses undertaken as part of their professional training (Luo, 2011). In the United Kingdom, various projects initiated by LIS faculty members have sought to address the perceived gap between practice and research by promoting practitioner engagement in research (Hall, 2010) and building capacity among practitioners and within the library and information sector to develop and carry out research projects (Hall, Kenna, \& Oppenheim, 2011).

\section{Issues in Dissemination}

A key recommendation from many authors is that communication and dissemination of research from faculty to practitioners should be improved (Ali, 1985; Haddow, 2010; Haddow \& Klobas, 2004; McClure, 1989). Goulding and Matthews (2002, p. 65) suggest that even when research results are available, they may not be accessible to practitioners, reducing the potential impact of the research.

The dimensions of the dissemination activity undertaken by academic faculty and practice-based researchers have been the subject of a range of studies involving bibliometrics or content analysis of published articles. Swigger (1985) explores author affiliations for 200 articles, suggesting that LIS faculty members publish a disproportionately large amount of the LIS literature. Haddow and Klobas (2004, p. 32) describe a low level of practitioner publication relative to the total size of the LIS profession.

However, studies also show that practitioners do make a considerable contribution to the published output of the LIS field. Swigger (1985) identifies nearly 50 percent of article authors as library practitioners, with nearly one third of the total number of authors being academic librarians. Fisher (1999, p. 62) identifies 53 percent of 204 article authors as library practitioners, and again the largest proportion (36 percent) are academic librarians. In their content analysis of 207 articles from practitioner and academic publications, Hildreth and Aytac (2007, p. 252) identify ninetyseven (47.1 percent) articles being authored solely by practitioners, concluding that the "six top journals that produce the greatest number of research articles are one-half practitioner and one-half academic." A study of a much more specific subset of the published literature that examined 117 articles from the ISIC (Information Seeking In Context) conference proceedings from 1996 to 2000 identifies a much smaller proportion of 
practitioner authors, finding only eight practitioners among 217 authors, which was 3.7 percent of the total (McKechnie et al., 2008).

Schlögl and Stock (2008) used a combination of methods (a reader survey, an editor survey, and an article-citation analysis) to explore the publication habits of German-speaking academics and practitioners in LIS. They identified practitioners as being responsible for a considerable amount of the periodical publications in the field, observing that "practitioners play an outstanding role in LIS journal communication. There might not be many disciplines where practitioners contribute so much to the knowledge base" (p. 650). However, the citation analysis also showed "only a low level of information exchange between practitioners and academics" (p. 660) with relatively little cross-over between the two sets of publications.

Klobas and Clyde (2010) report finding that fifty of 121 (41.3 percent) article authors on topics relating to school librarianship who participated in their survey of author views of research and publication in LIS and their journal preferences were practitioners. They note that, with the exception of respondents' differing levels of confidence in conducting and writing up research, "the views and motivations of full professors, other researchers and practitioner-authors were surprisingly similar" (p. 237).

The value of more informal types of dissemination is also briefly discussed in a number of articles. Ali (1985) reports how a survey of U.K. and U.S. library practitioners shows the value of personal contacts in disseminating research results. Clapton (2010, p. 8) and Haddow (2010, p. 40) also mention the potential role of more informal types of web publication, such as blogs and wikis, in disseminating research.

\section{Methodology}

The research took place between February and October 2012 and adopted a primarily inductive, qualitative approach. The first two research questions were addressed through two focus groups, which were targeted respectively at early-career researchers and experienced faculty members, in both cases concentrating on representatives of the school's Library and Information Management research area, which includes four groups (with overlapping membership) working in the fields of libraries and the information society, knowledge and information management, educational informatics, and health informatics. School e-mail lists and individual e-mail invitations were used to recruit participants. The third research question was addressed through content analysis of a purposive sample of research articles published by iSchool faculty working in the Library and Information Management research area. The project received ethics approval from the iSchool in accordance with the University of Sheffield's Research Ethics Procedure.

The first focus group took place on March 21, 2012, and was designed 
to give researchers at the start of their careers the opportunity to discuss their expectations and aspirations regarding their research and its potential impact. Four doctoral students and one newly appointed junior faculty member participated. The second focus group took place on June 28, 2012, shortly after the end of the spring semester examination period. It was intended to provide more senior researchers and faculty members with the opportunity to reflect on the views expressed by members of the first focus group and to discuss their own strategies and experiences of linking research to practice. Five faculty members of different ranks up to and including full professor participated. Both focus groups lasted for about 1 hour. The discussions were recorded and transcribed in full, and each focus group member was provided with a copy of the transcript as part of a respondent-validation exercise (Bryman, 2004, p. 274). The transcripts were coded and analyzed using thematic analysis, facilitated by the qualitative analysis software NVivo.

The content analysis was performed on thirty-seven articles published by ten Sheffield iSchool faculty during the period from 2008 to 2012. The articles were selected to form a sample of manageable size that would at the same time reflect the diversity of topics and methods characterizing the output of ten full-time and part-time faculty members across the four groups in the Library and Information Management research area. The articles were not selected on the basis of any overt linking of research and practice. Although content analysis is sometimes described as a technique for applying quantitative measures to the analysis of qualitative data, such as documents or images (Bryman, 2004, p. 181), it also accommodates qualitative approaches, with or without quantitative elements (White \& Marsh, 2006, pp. 36-37). Content analysis of journal articles has been used to explore the relationship between research and practice in a number of previous studies (Haddow, 2010; Hildreth \& Aytac, 2007; McKechnie et al., 2008; Swigger, 1985) or to categorize or classify the domains covered by the LIS literature (Koufogiannakis et al., 2004); other bibliometric techniques, including citation analysis, have also been used to explore these themes (Saracevic \& Berk, 1973; Schlögl \& Stock, 2008). The present sample is much smaller than the 100 to 200 articles analyzed in previous studies (Fisher, 1999; Hildreth \& Aytac, 2007; McKechnie et al., 2008; Swigger, 1985) but is distinctive in its focus on the output of an individual LIS department.

\section{Focus Group Results}

Participants were informed that the purpose of the focus groups was to explore "the strategies that researchers in the Information School (iSchool) at the University of Sheffield adopt in order to translate research findings into practice." Participants in both groups were asked why they conducted research, how experience as a practitioner affected their views of research, 
whether and where they felt their research had an impact, and what channels there were for getting research to interested people. A key theme to emerge from the focus groups was that the nature of the impact is affected by the nature of the research and of the tools used to disseminate it; the nature of the research in turn is affected by the reasons why it is being undertaken. Responses are identified here by alphanumeric codes denoting the focus group in which they were recorded-EC (meaning "early career," participants in the first focus group) or FM (meaning "faculty members," participants in the second focus group) —followed by the number assigned to participants within their respective groups.

\section{Reasons for Doing Research}

All the focus group participants had been practitioners at some point in their careers. This was clearly a factor in their decision to do research, and in the nature of the research they chose to do, for both groups, for example: "I see myself as a librarian who is doing research, so the idea of contributing to the profession through the research that I do is quite key to how I see my role at the moment" (EC4); "Investigating things, in order to understand things better, to find out what was going on in the library world, and always with the ultimate aim of improving my practice and ... contribute to improving other people's practice as well, but that is really why I have sort of been interested in this area" (FM3); and "The ultimate motivation is to be useful" (FM1). Two of the early-career researchers (EC4, EC5) described research projects carried out in the workplace that gave them an appetite for research and encouraged their return to academia as doctoral students.

Clearly, though, some of the participants regarded research as a vocation, particularly the faculty members, who had all deliberately chosen to move from careers as practitioners to roles in the academy, for example: "You do research because you have got to, you are driven to do it, you just have an intrinsic interest in something ... and the best way to find out, so it's a fairly sort of natural drive" (FM1). The idea of looking things up and finding things out is central to traditional conceptions of the role of the librarian and translates naturally into research activities, as illustrated by two faculty comments: "I think of a librarian as being a Sherlock Holmes type character who is always investigating and always researching and trying to find things out" (FM5), and "I began thinking about research when I was in a practitioner context" (FM1). Similar sentiments were expressed in the early-career group, for example: "My primary motivation is that I find it interesting, research interesting for its own sake" (EC3); and "I have never been driven by a practical kind of aspect, it's been more of a whether something has been interesting" (EC2). The word "selfish" was also used here, by two early-career researchers and one faculty member. 
There were differences in the way that the transition from practitioner to academic researcher was perceived. For one member, it seemed to have been a real step-change, "It certainly took me a while to fully grasp what it was to be a researcher and now I think it's really exciting . . . but . . . it certainly wasn't something that was immediate and natural to me " (FM2), a sentiment that was echoed by FM4: "It's the one area of my practice that I could do with more confidence in." However, a third member presented it as a more natural evolution, identifying differences between her previous literature-based research and development projects but seeing the different types of investigation as a continuum: "I see it more as a spectrum really, and I wouldn't devalue too much the type of research that I did when I was a practitioner, because I think that's really what gave me the interest in becoming an academic" (FM3). Two early-career researchers similarly mentioned their positive experience of practice-based research influencing their decisions to do doctoral research in academia, for example: "It was also having the experience of showing how practice and research can actually work together in quite a practical way" (EC4); two researchers (EC3, EC4) specifically mentioned their enjoyment of master's research projects as formative experiences.

The pleasure derived from discovery for its own sake was a common theme in both groups and was especially evident among the early-career research group, for example: "My project does have a practical goal . . . but that isn't really what motivates me, or drives me in my work. It's more the abstract - the theory behind it, and better understanding the subject matter, and hopefully adding to other people's understanding of the subject matter" (EC3); "I think holding onto the idea that pursuing knowledge for its own sake is a good thing, I think it's really important to hold on to that idea ... I enjoy the research for its own sake" (EC1); and "When I was in a job which didn't involve research . . . I always missed having a part of the job where you find out new things and look more deeply into things, so I think that is one of the main things I get from doing research" (EC1).

However, in addition to the personal factors illustrated above, participants from both groups recognized that research was part of their role in the iSchool, for example: "It became important because it was . . . a requirement" (EC5), and "Let's not beat about the bush and be romantic about this, we are obliged to as part of our job role" (FM5). The University of Sheffield's mission statement, "to discover and understand," a contemporary rendering of a Latin motto previously translated as "to know the causes of things" (University of Sheffield, 2012), was quoted positively in this context: "Yes, I think the university strapline, bringing it in, says it quite a bit for me, that is 'to discover and understand.' So it's about discovering new things and understanding what is going on in the world around you" (FM4). 


\section{Nature of Research Impacts}

Both focus groups discussed the impact of research, including the nature of research impacts. In both groups, concern was raised about limited one-dimensional views of research impact, which, on the one hand, might be quite unrealistic in expecting immediate outcomes from fundamental work or, on the other hand, might encourage publication in high-impact journals that were unlikely to be read by the intended beneficiaries of the research, for example: "I suppose the more you delve into psychology of the way people use information the more you get into the maze, and the more your contribution is possibly revealing the fact that we can't study this simplistically and some of the earlier simplistic models are simply not adequate. But it doesn't lend itself very well to immediate impact of the type which seems to be now required" (FM1); and "There is tension between the academic incentive to publish in a peer review journal and the actual potential audience" (EC4).

Impact for funding bodies. Some discussion centered on the Research Excellence Framework (REF), the new system introduced by the U.K. highereducation funding bodies for assessing the quality of research in universities, which places more emphasis on impact than previous systems, with impact defined in this context as "the 'reach and significance' of impacts on the economy, society and/or culture" (REF, 2012, p. 6), rather than in terms of academic impact, as represented by bibliometric analysis, journal impact factors, or similar measures. Concerns were raised about the limited interpretation of impact promoted by this exercise.

Unsurprisingly, this was a more prominent theme in the second focus group, as it is essentially faculty research that is assessed in this way and participants were conscious of the imminent requirement to produce "impact case studies." REF was mentioned only once by the early-career researchers, one of whom commented: "I do use my research in my teaching, but I think in REF terms that doesn't actually count as impact" (EC1). What did, or did not, count as impact in REF terms was a topic of greater interest to members of the second focus group, who expressed a range of views, for example: “I don't actually feel it's appropriate to let REF drive what we do and I think there is too much of that happening. . . . I think the way REF . . characterizes impact . . . is extremely unhelpful” (FM3); "I do know people in this profession that have had a tremendous impact . . . but when you actually look at the work that they produce it wouldn't hack it in REF" (FM5).

Impact in teaching activities. The potential tension between REF-oriented views of impact and the role of researcher-as-teacher in an academic setting was also discussed. Participants in both groups emphasized the importance of their teaching as a way of helping to ensure that their research had continuing impact among practitioners, often reiterating the point, for example: "We don't always see that impact. We don't know what they 
are up to, and their organizations, and how they are bringing the research that they have heard about as a student into . . . their jobs and their practice. So again, I think . . . there is an impact that REF wouldn't consider" (FM4); and "We use our research to inform our teaching and that has a massive impact on the students that graduate every single year. You know, we have what thirty to forty librarians graduating every year who have been impacted on by our research, and we have no way really of measuring what they then get up to" (FM4).

Members of the early-career group had mixed views on research having an impact in the classroom. Researchers involved in teaching undergraduate and master's students in information management programs had experiences that differed from those teaching master's in librarianship students and felt that they had little or no impact on the information management students. In contrast, EC1 described the librarianship students as "always quite committed," after confirming "I do use my research in my teaching ... I like to think it's something which they might have not thought about before, and after my lecture maybe they will do." Other early-career researchers felt they had more impact on students when working with small groups, and EC5 suggested that another way for researchers to have impact was in the transfer of the skills gained in research to master's students: "The research skills that we acquire, that we are able to pass them on to other people ... I think that is one way of making impact as well."

Impact through personal contacts. Finally, the potential for impact through both formal and informal personal interactions was recognized, particularly by faculty members who felt their backgrounds as practitioners made a difference in helping them to disseminate effectively and in shaping their ideas for research projects, identifying reciprocal impacts (practice impacting on research), for example: "You have an understanding then of how to, if you like, translate that research into something that practitioners can understand and latch onto and take and use in the work environment, because the language of a researcher can be very different to a practitioner language" (FM5); and "if you are already quite well connected in the networks, [it means] that you are more likely to disseminate and pick up projects and things that ... practitioners are interested in and also you are more aware of some of the applications" (FM2). FM4 similarly observed that "many of the things that I have investigated, the ideas . . . have come through my knowledge and contacts with practice." Masters dissertations were highlighted here, as projects that were "engaged with external organizations, so ... having an impact there" (FM2). FM5 also noted that practitioners were "becoming more receptive to researchers now, because we are in an evidence-based profession."

Two faculty members (FM2, FM3) mentioned invitations from practitioners to speak at conferences, carry out consultancy, and run workshops 
for practitioner groups as a result of publishing, or otherwise publicizing, their research, identifying "signals that what you are doing is of interest and value to the profession" (FM3) but also noting that it was sometimes hard to trace the impact of their work: "It's quite encouraging, I mean, because often you do keep in contact and get an idea [about what happened afterwards] . . . sometimes you can see directly that they are using a model, or something like that; but sometimes it is something that doesn't actually get documented" (FM2). Two other faculty members (FM4, FM5) described seeing three master's in librarianship graduates at the Librarians' Information Literacy Annual Conference (a venue for both academic and practitioner research) and explained how faculty copresenting articles with students based on their master's dissertations at conferences had encouraged graduates to carry on researching and publishing as practitioners after they moved into employment, reinforcing the message from early-career researchers about research experience in master's programs stimulating practitioners to do research.

Conferences were also highlighted in the early-career group. EC5 suggested that face-to-face feedback was particularly valuable, even though fewer people were involved: "I think the thing that has had the most impact was when I really went to conferences and spoke to people." Similarly, close and informal associations with colleagues could have an impact on the nature of the research itself or on the local context in which the research was being conducted, for example: "By and large the most successful periods if you like were working as part of a team, and I suppose you could say that I had a certain amount of impact within that, that team," and "the best ideas either myself or apparently people have come up with have been in coffee shops and pubs, rather than actually in an office" (EC2).

\section{Social and Other Media}

Channels for communicating about research were discussed in both focus groups, ranging from formal publication in peer-reviewed journals to more informal publication through social media. EC1 and EC3 both thought that peer-reviewed articles had very little impact on practitioners, EC1 referring to "a massive research-practice divide" in her area (public libraries). EC1 had disseminated her research via a practitioner journal, and EC4 expressed the opinion that "more often people pick up on things through non peer review publications," echoing EC3's comment that academic journal articles were "of limited relevance to people on the front line of public librarianship." FM3 said that she had feedback showing that the books she had published previously "had actually made quite a lot of impact," arguing that "ultimately, for practitioners ... books are things that they actually ... find useful, and they tend to have a more ... lasting impact." 
Two early-career researchers had disseminated their work as practical information products designed for immediate use by intended research beneficiaries. EC5 had published two information leaflets for different user groups, using simple language and a concise format, which had apparently been well received: "It is out in the community, people are reading it, and I think it is making a contribution." EC1 had created book lists that had been publicized to practitioners through the web site of their professional body, the Chartered Institute of Library and Information Professionals, and via her university webpage and Twitter, with a similarly positive reception ("People have said that they find it incredibly useful"), although she was concerned about the reach of her efforts ("I think it's still relatively small numbers").

One member of each focus group was a regular blogger. The earlycareer blogger (EC4) said that she had originally conceived the reach of her blog in a rather limited way, "My motivation for setting up a blog was more than anything to allow people who I had worked with in the past to see what I was doing and potentially to have some kind of input," but revealed that it had been viewed around 1,500 times during the thirteen months that it had been running, and had generated some interest: "Some people contact me about my blog . . . there have been a couple of contacts initiated through that blog where I have been able to respond to questions, quite practical questions, that people have raised about the subject area." The faculty blogger (FM2) has been invited to talk about her research at numerous conferences and expressed the view that, in recent years, it was partly because of her widely read blog: "One of the reasons why I get invited is because I have got this sort of continuous demonstration [of knowing what she is talking about]." FM2 also described how she talked about other people's research: "On the blog, I mean, I am actually promoting others and ... I see that as part of my contribution to research in practice."

The potential value of Twitter was recognized by both groups, but there was clear ambivalence toward it, for example: "I don't personally like Twitter that much, but I decided I had got to get more engaged in Twitter because ... particularly the young professionals, it seems to be the go-to place for them ... I am never going to love it" (FM2); "social media kind of sends a little shiver down my spine ... I don't tweet" (EC3); and "Twitter has actually been incredibly useful for getting the word out . . . I think it has to be used strategically and also I have realized impact is kind of an ongoing thing, so you really have to keep up your Twitter presence . . . to be honest it is a time drain and sometimes I find that I am so busy having impact that I am not actually progressing the actual research any further" (EC1). FM5 highlighted Twitter's value for current awareness: "Certainly I pick up on things on Twitter... And that is increasingly how news breaks... and sometimes I think, oh gosh, if I wasn't on here, I would 
have missed that, because the younger people coming into the profession are definitely using it more and more." FM4 also noted its increasing use during conference sessions, explaining how someone had tweeted about her research presentation at the Librarians' Information Literacy Annual Conference (LILAC) and "shared that via Twitter with the world."

FM2 went on to explain how different social media "all have their impact, but in ... different kinds of ways" and advocated "fitting your social media profile together and working out which is the best medium," describing how she put past presentations on SlideShare, had used YouTube for a presentation that she could not deliver in person, and could announce that on her blog and tweet it. Two early-career researchers (EC1, EC5) had engaged to a limited extent with Academia.edu, a networking site aimed specifically at academic researchers, and felt it had potential, which they had not been able to exploit fully while still at the early stages of their research. FM1 reinforced their positive view of the site, describing how you can "download papers and ... set up fairly quickly networks of interesting people," and FM2 confirmed Academia.edu as "the place to have your profile, as much as possible about your papers," noting that her articles were "getting looked up more" as a result of developing her profile there.

Thus, in both focus groups, attention was drawn to the gap between publication for wide dissemination, including through less formal professional and informal social media, and the institutional incentives for publishing in less widely disseminated peer-reviewed publications, although there were indications that researchers had started to identify strategies integrating different types and styles of media to fulfill their academic and professional goals.

\section{Content Analysis Results}

The thirty-seven articles that were analyzed included two preprint versions available from departmental or institutional repositories (Sen \& Ford, 2009; Webber, 2010). Data were collected from each article using a data extraction sheet, covering twenty-nine criteria across five categories, as shown in table 1 . The criteria included both objective dimensions, such as the date of publication and number of authors, and more subjective characteristics, such as whether the motivation for the research was described with reference to practice.

\section{Basic Characteristics of the Sample}

Key characteristics of the articles are shown in table 2. The details include an indication of the length of each document. The articles ranged in length from around 4,875 to 16,670 words ( mean $=7792.4$; median $=$ 7,582 ). Although these appear to be precise calculations, they should be treated as indicative counts rather than exact figures, because the calcula- 
Table 1. Content analysis criteria for data extraction

\begin{tabular}{|c|c|c|c|c|}
\hline Description & Subject matter & Methodology & $\begin{array}{l}\text { Statements } \\
\text { relating research } \\
\text { to practice }\end{array}$ & References \\
\hline Title of paper & Main topic & $\begin{array}{l}\text { Method of data } \\
\text { collection }\end{array}$ & $\begin{array}{l}\text { Motivation from } \\
\text { practice to } \\
\text { conduct the } \\
\text { research }\end{array}$ & $\begin{array}{l}\text { Number of } \\
\text { references }\end{array}$ \\
\hline $\begin{array}{l}\text { Date of } \\
\text { publication }\end{array}$ & Main keywords & Size of sample & $\begin{array}{l}\text { Practical } \\
\text { or policy } \\
\text { implications } \\
\text { from the } \\
\text { research }\end{array}$ & $\begin{array}{l}\text { Types of } \\
\text { references }\end{array}$ \\
\hline Title of journal & $\begin{array}{l}\text { Interdisciplinary } \\
\text { aspects }\end{array}$ & $\begin{array}{l}\text { Involvement of } \\
\text { practitioners }\end{array}$ & $\begin{array}{l}\text { Specific } \\
\text { strategies for } \\
\text { transferring } \\
\text { research into } \\
\text { practice }\end{array}$ & $\begin{array}{l}\text { Number of } \\
\text { references } \\
\text { providing } \\
\text { URLs }\end{array}$ \\
\hline $\begin{array}{l}\text { Orientation of } \\
\text { journal }\end{array}$ & $\begin{array}{l}\text { Specific problem } \\
\text { area }\end{array}$ & $\begin{array}{l}\text { Timeframe of } \\
\text { study }\end{array}$ & $\begin{array}{l}\text { Specific } \\
\text { outputs for } \\
\text { practitioners } \\
\text { from the } \\
\text { research }\end{array}$ & \\
\hline $\begin{array}{l}\text { Availability of } \\
\text { journal }\end{array}$ & $\begin{array}{l}\text { Audience or } \\
\text { target group }\end{array}$ & $\begin{array}{l}\text { Context or } \\
\text { setting }\end{array}$ & $\begin{array}{l}\text { Implications } \\
\text { for research } \\
\text { arising from } \\
\text { the work }\end{array}$ & \\
\hline $\begin{array}{l}\text { Number of } \\
\text { authors }\end{array}$ & & Type of analysis & & \\
\hline \multicolumn{5}{|l|}{$\begin{array}{l}\text { Affiliation of } \\
\text { author }(\mathrm{s})\end{array}$} \\
\hline \multicolumn{5}{|l|}{ Word count } \\
\hline \multicolumn{5}{|l|}{ Source of funding } \\
\hline $\begin{array}{l}\text { Number of } \\
\text { downloads }\end{array}$ & & & & \\
\hline
\end{tabular}

tion generally includes superfluous material (such as headers and footers), as well as the substantive content of the article, although reference lists and appendices are excluded. The number of references also varied considerably, from twelve to 116 .

The articles were published in twenty-one journals, only two of which (Journal of the American Society for Information Science and Technology and Studies in Higher Education) do not mention both practice and research in their journal descriptions but focus specifically on research (Taylor and Francis, 2012; Wiley, 2012). Of the twenty-one journals, one (ITALICS) was an open-access publication and six were potentially available to U.K. LIS practitioners through membership of professional associations such as the 
Table 2. Key characteristics of papers sampled

\begin{tabular}{|c|c|c|c|c|}
\hline Author (Date) & Title, Journal & $\begin{array}{l}\text { Interdisciplinary } \\
\text { aspects }\end{array}$ & Words & $\begin{array}{c}\text { Ref- } \\
\text { erences }\end{array}$ \\
\hline $\begin{array}{l}\text { Ayatollahi, Bath, } \\
\text { \& Goodacre } \\
(2009)\end{array}$ & $\begin{array}{l}\text { Paper-based versus computer- } \\
\text { based records in the emergency } \\
\text { department: Staff preferences, } \\
\text { expectations, and concerns, } \\
\text { Health Informatics Journal }\end{array}$ & $\begin{array}{l}\text { Health admin- } \\
\text { istration, } \\
\text { Records man- } \\
\text { agement }\end{array}$ & 5613 & 29 \\
\hline Bath (2008) & $\begin{array}{l}\text { Health informatics: Current issues } \\
\text { and challenges, Journal of Infor- } \\
\text { mation Science }\end{array}$ & Health & 9728 & 66 \\
\hline Birdi (2011) & $\begin{array}{l}\text { Investigating fiction reader charac- } \\
\text { teristics using personal construct } \\
\text { theory, Aslib Proceedings }\end{array}$ & $\begin{array}{l}\text { Sociology, } \\
\text { Literature }\end{array}$ & 8807 & 53 \\
\hline $\begin{array}{l}\text { Birdi \& Syed } \\
\quad(2011)\end{array}$ & $\begin{array}{l}\text { Exploring reader response to } \\
\text { minority ethnic fiction, Library } \\
\text { Review }\end{array}$ & $\begin{array}{l}\text { Literature, } \\
\text { Publishing }\end{array}$ & 6736 & 38 \\
\hline $\begin{array}{l}\text { Birdi, Wilson, \& } \\
\text { Mansoor } \\
\quad(2012)\end{array}$ & $\begin{array}{l}\text { "What we should strive for is Brit- } \\
\text { ishness": An attitudinal investiga- } \\
\text { tion of ethnic diversity and the } \\
\text { public library, Journal of Librari- } \\
\text { anship and Information Science }\end{array}$ & Sociology & 7139 & 53 \\
\hline $\begin{array}{l}\text { Bird, Wilson, \& } \\
\text { Tso (2009) }\end{array}$ & $\begin{array}{l}\text { The nature and role of empathy } \\
\text { in public librarianship, Journal } \\
\text { of Librarianship and Information } \\
\text { Science }\end{array}$ & Psychology & 6823 & 28 \\
\hline $\begin{array}{l}\text { Brewster \& Sen } \\
\quad(2010)\end{array}$ & $\begin{array}{l}\text { Quality signposting: The role of } \\
\text { online information prescription, } \\
\text { Health Information and Libraries } \\
\text { Journal }\end{array}$ & Health services & 4875 & 30 \\
\hline $\begin{array}{l}\text { Brown \& Sen } \\
\quad(2010)\end{array}$ & $\begin{array}{l}\text { The undergraduate prospectus as } \\
\text { a marketing tool for academic } \\
\text { libraries, New Review of Academic } \\
\text { Librarianship }\end{array}$ & Marketing & 7111 & 38 \\
\hline $\begin{array}{l}\text { Chen, Nunes, } \\
\text { Zhou, \& Peng } \\
\text { (2011) }\end{array}$ & $\begin{array}{l}\text { Expanding the concept of require- } \\
\text { ments traceability: The role of } \\
\text { electronic records management } \\
\text { in gathering evidence of crucial } \\
\text { communications and negotia- } \\
\text { tions, Aslib Proceedings }\end{array}$ & Management & 8426 & 45 \\
\hline Corrall (2008) & $\begin{array}{l}\text { Information literacy strategy devel- } \\
\text { opment in higher education: An } \\
\text { exploratory study, International } \\
\text { Journal of Information Management }\end{array}$ & $\begin{array}{l}\text { Management } \\
\text { studies, High- } \\
\text { er education }\end{array}$ & 7848 & 84 \\
\hline Corrall (2010) & $\begin{array}{l}\text { Educating the academic librar- } \\
\text { ian as a blended professional: } \\
\text { A review and case study, Library } \\
\text { Management }\end{array}$ & Education & 9048 & 102 \\
\hline $\begin{array}{l}\text { Corrall \& } \\
\quad \text { Sriborisutsakul } \\
(2010)\end{array}$ & $\begin{array}{l}\text { Evaluating intellectual assets in } \\
\text { university libraries: A multi-site } \\
\text { case study from Thailand, Jour- } \\
\text { nal of Information and Knowledge } \\
\text { Management }\end{array}$ & $\begin{array}{l}\text { Performance } \\
\text { management, } \\
\text { Management } \\
\text { studies }\end{array}$ & 8008 & 63 \\
\hline Cox (2008) & $\begin{array}{l}\text { An exploration of concepts of com- } \\
\text { munity through a case study of } \\
\text { UK university web production, } \\
\text { Journal of Information Science }\end{array}$ & $\begin{array}{l}\text { Computer sys- } \\
\text { tems, Social } \\
\text { networks }\end{array}$ & 10182 & 58 \\
\hline
\end{tabular}


Table 2. continued

\begin{tabular}{|c|c|c|c|c|}
\hline Author (Date) & Title, Journal & $\begin{array}{l}\text { Interdisciplinary } \\
\text { aspects }\end{array}$ & Words & $\begin{array}{l}\text { Ref- } \\
\text { erences }\end{array}$ \\
\hline $\begin{array}{l}\text { Cox \& Blake } \\
\quad(2011)\end{array}$ & $\begin{array}{l}\text { Information and food blogging as } \\
\text { serious leisure, Aslib Proceedings }\end{array}$ & $\begin{array}{l}\text { Leisure studies, } \\
\text { Consump- } \\
\text { tion (food), } \\
\text { Photography }\end{array}$ & 8170 & 44 \\
\hline $\begin{array}{l}\text { Cox, Clough, \& } \\
\text { Siersdorfer. } \\
\text { (2011) }\end{array}$ & $\begin{array}{l}\text { Developing metrics to characterize } \\
\text { Flickr groups, Journal of the Ameri- } \\
\text { can Society for Information Science } \\
\text { and Technology }\end{array}$ & $\begin{array}{l}\text { Computer } \\
\text { systems }\end{array}$ & 9053 & 31 \\
\hline $\begin{array}{l}\text { Cox, Levy, } \\
\text { Stordy, \& } \\
\text { Webber (2008) }\end{array}$ & $\begin{array}{l}\text { Inquiry-based learning in the first- } \\
\text { year information management } \\
\text { curriculum, ITALICS }\end{array}$ & Education & 6505 & 12 \\
\hline Ford (2008) & $\begin{array}{l}\text { Educational informatics, Annual } \\
\text { Review of Information Science and } \\
\text { Technology, }\end{array}$ & Education & 16670 & 116 \\
\hline $\begin{array}{l}\text { Ford, Eaglestone, } \\
\text { Madden, \& } \\
\text { Whittle. } \\
\text { (2009) }\end{array}$ & $\begin{array}{l}\text { Web searching by the "general } \\
\text { public": An individual differ- } \\
\text { ences perspective, Journal of } \\
\text { Documentation }\end{array}$ & & 11369 & 57 \\
\hline $\begin{array}{l}\text { Gorrell, } \\
\quad \text { Eaglestone, } \\
\text { Ford, } \\
\text { Holdridge, \& } \\
\text { Madden. } \\
\text { (2009) }\end{array}$ & $\begin{array}{l}\text { Towards "metacognitively aware" } \\
\text { IR systems: An initial user study, } \\
\text { Journal of Documentation }\end{array}$ & $\begin{array}{l}\text { Computer } \\
\text { science, } \\
\text { Psychology }\end{array}$ & 5903 & 41 \\
\hline $\begin{array}{l}\text { Gorrell, Ford, } \\
\text { Eaglestone, } \\
\text { Holdridge, \& } \\
\text { Madden } \\
\text { (2011) }\end{array}$ & $\begin{array}{l}\text { Countering method bias in } \\
\text { questionnaire-based user studies } \\
\text { about metacognition, Journal of } \\
\text { Documentation }\end{array}$ & $\begin{array}{l}\text { Computer } \\
\text { science, } \\
\text { Social science }\end{array}$ & 6155 & 53 \\
\hline $\begin{array}{l}\text { Guillame \& Bath } \\
\text { (2008) }\end{array}$ & $\begin{array}{l}\text { A content analysis of mass media } \\
\text { sources in relation to the MMR } \\
\text { vaccine scare, Health Informatics } \\
\text { Journal }\end{array}$ & $\begin{array}{l}\text { Media, Journal- } \\
\text { ism, Health } \\
\text { information }\end{array}$ & 5654 & 19 \\
\hline $\begin{array}{l}\text { Gumulak \& } \\
\text { Webber } \\
\text { (2011) }\end{array}$ & $\begin{array}{l}\text { Playing video games: Learning } \\
\text { and information literacy, Aslib } \\
\text { Proceedings }\end{array}$ & $\begin{array}{l}\text { Education, Video } \\
\text { games }\end{array}$ & 6352 & 40 \\
\hline $\begin{array}{l}\text { Idrees, } \\
\text { Vasconcelos, } \\
\text { \& Cox (2011) }\end{array}$ & $\begin{array}{l}\text { The use of grounded theory in } \\
\text { PhD research in knowledge } \\
\text { management: A model four stage } \\
\text { research design, Aslib Proceedings }\end{array}$ & $\begin{array}{l}\text { Knowledge } \\
\text { management }\end{array}$ & 6131 & 66 \\
\hline $\begin{array}{l}\text { Lameras, Levy, } \\
\text { Paraskakis, \& } \\
\text { Webber } \\
\text { (2012) }\end{array}$ & $\begin{array}{l}\text { Blended university teaching using } \\
\text { virtual learning environments: } \\
\text { Conceptions and approaches, } \\
\text { Instructional Science }\end{array}$ & $\begin{array}{l}\text { Computer } \\
\text { science, } \\
\text { Education }\end{array}$ & 8246 & 27 \\
\hline $\begin{array}{l}\text { Levy \& Petrulis } \\
\quad \text { (2012) }\end{array}$ & $\begin{array}{l}\text { How do first-year university } \\
\text { students experience inquiry and } \\
\text { research, and what are the } \\
\text { implications for the practice of } \\
\text { inquiry-based learning? Studies } \\
\text { in Higher Education }\end{array}$ & Education & 7819 & 47 \\
\hline
\end{tabular}




\begin{tabular}{|c|c|c|c|c|}
\hline Author (Date) & Title, Journal & $\begin{array}{l}\text { Interdisciplinary } \\
\text { aspects }\end{array}$ & Words & $\begin{array}{c}\text { Ref- } \\
\text { erences }\end{array}$ \\
\hline $\begin{array}{l}\text { Levy, Aiyegabyo, } \\
\text { \& Little (2009) }\end{array}$ & $\begin{array}{l}\text { Designing for inquiry-based learn- } \\
\text { ing with the Learning Activity } \\
\text { Management System, Journal of } \\
\text { Computer-Assisted } \\
\text { Learning }\end{array}$ & $\begin{array}{l}\text { Computer } \\
\text { science, } \\
\text { Education }\end{array}$ & 7880 & 37 \\
\hline $\begin{array}{l}\text { MacDonald, } \\
\text { Bath, \& Booth } \\
\text { (2011) }\end{array}$ & $\begin{array}{l}\text { Information overload and infor- } \\
\text { mation poverty: Challenges for } \\
\text { healthcare services managers? } \\
\text { Iournal of Documentation }\end{array}$ & $\begin{array}{l}\text { Health } \\
\quad \text { administration }\end{array}$ & 10066 & 81 \\
\hline $\begin{array}{l}\text { Mansourian, } \\
\text { Ford, Webber, } \\
\text { \& Madden } \\
(2008)\end{array}$ & $\begin{array}{l}\text { An integrative model of "informa- } \\
\text { tion visibility" and "information } \\
\text { seeking" on the } \\
\text { web, Program }\end{array}$ & $\begin{array}{r}\text { Computer } \\
\text { science, } \\
\text { Biology }\end{array}$ & 5881 & 24 \\
\hline $\begin{array}{l}\text { McPherson \& } \\
\text { Nunes (2008) }\end{array}$ & $\begin{array}{l}\text { Critical issues for e-learning } \\
\text { delivery: What may seem obvious } \\
\text { is not always put into practice, } \\
\text { Journal of Computer Assisted } \\
\text { Learning }\end{array}$ & Education & 5872 & 50 \\
\hline $\begin{array}{l}\text { Nazari \& } \\
\text { Webber } \\
\text { (2011) }\end{array}$ & $\begin{array}{l}\text { What do the conceptions of geo/ } \\
\text { spatial information tell us about } \\
\text { information literacy? Journal of } \\
\text { Documentation }\end{array}$ & Education & 7226 & 33 \\
\hline $\begin{array}{l}\text { Polding, Nunes, } \\
\text { \& Kingston } \\
\text { (2008) }\end{array}$ & $\begin{array}{l}\text { Assessing e-book model sustain- } \\
\text { ability, Journal of Librarianship and } \\
\text { Information Science }\end{array}$ & Publishing & 9062 & 37 \\
\hline $\begin{array}{l}\text { Sen \& Ford } \\
\quad(2009)\end{array}$ & $\begin{array}{l}\text { Developing reflective practice in } \\
\text { LIS education: The SEA-change } \\
\text { model of reflection, Education for } \\
\text { Information }\end{array}$ & Education & 6064 & 27 \\
\hline $\begin{array}{l}\text { Tam, Cox, \& } \\
\quad \text { Bussey }(2009)\end{array}$ & $\begin{array}{l}\text { Student user preferences for } \\
\text { features of next generation } \\
\text { OPACs: A case study of University } \\
\text { of Sheffield international stud- } \\
\text { ents, Program }\end{array}$ & $\begin{array}{l}\text { Computer } \\
\text { systems }\end{array}$ & 8116 & 39 \\
\hline $\begin{array}{c}\text { Vasconcelos } \\
\quad(2008)\end{array}$ & $\begin{array}{l}\text { Dilemmas in knowledge manage- } \\
\text { ment, Library Management }\end{array}$ & Management & 9075 & 65 \\
\hline Webber (2010) & $\begin{array}{l}\text { Investigating modes of student } \\
\text { inquiry in Second Life as part } \\
\text { of a blended approach, Interna- } \\
\text { tional Journal of Virtual and Pers- } \\
\text { onal Learning Environments }\end{array}$ & Education & 7582 & 40 \\
\hline $\begin{array}{l}\text { Wilson \& Corrall } \\
\quad(2008)\end{array}$ & $\begin{array}{l}\text { Developing public library managers } \\
\text { as leaders: Evaluation of a } \\
\text { national leadership development } \\
\text { programme, Library Management }\end{array}$ & Management & 7091 & 38 \\
\hline $\begin{array}{l}\text { Zhou, } \\
\text { Vasconcelos, \& } \\
\text { Nunes (2008) }\end{array}$ & $\begin{array}{l}\text { Supporting decision making in } \\
\text { risk management through an } \\
\text { evidence-based information sys- } \\
\text { tems project risk checklist, Infor- } \\
\text { mation Management and Computer } \\
\text { Security }\end{array}$ & Management & 6032 & 61 \\
\hline
\end{tabular}


Chartered Institute of Library and Information Professionals (2012) or ASLIB, The Association for Information Management (2012); in the case of ASLIB, members can choose two journals from seven LIS titles published by Emerald (which goes beyond those historically published by the organization). Figure 1 shows the distribution of articles across journals that are more likely to be accessible to practitioners as a result of personal or institutional memberships.

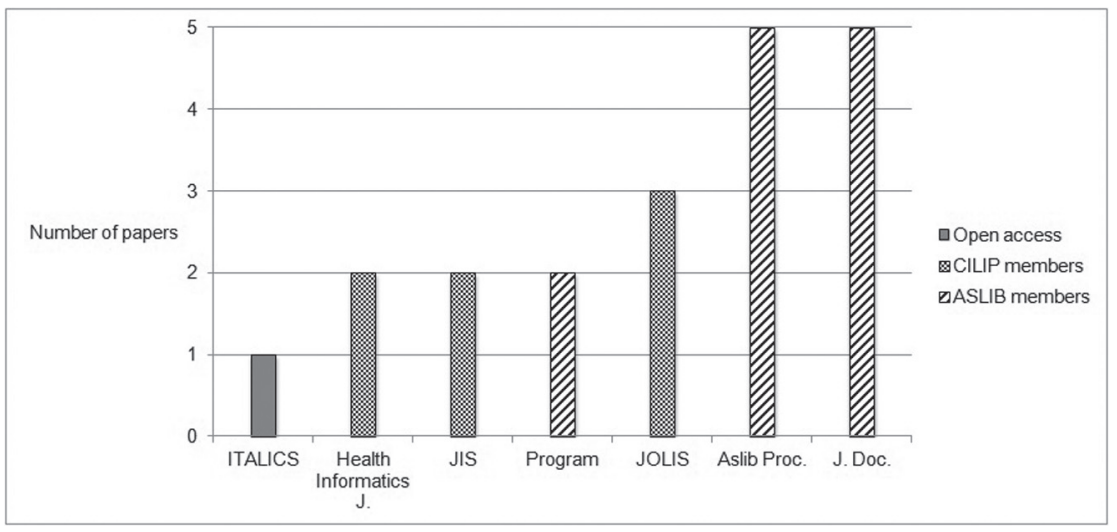

Figure 1. Availability of papers to practitioners.

In addition, full-text versions for seven of the thirty-seven articles (21.6 percent) were available in some form from White Rose Research Online (2011), the shared repository for research outputs from the universities of Leeds, Sheffield, and York (three as publisher preprints and four as author preprints or pre-peer-review e-prints). Another article was available as an author preprint from the personal web pages of a faculty member.

Authorship of Articles and Dimensions of Collaboration

The articles were authored by between one and five contributors. The most frequent number of authors for an article was two $(n=12)$. Eight coauthors of seven articles were faculty members from other schools or departments in the University of Sheffield. Six coauthors were faculty from other higher-education institutions in the United Kingdom; an additional contributor to another article was a university consultant. Nine contributors to eight articles were affiliated to institutions in countries beyond the United Kingdom (including Canada, Iran, Germany, Thailand, 
and the United States), demonstrating the international dimension of the iSchool's research; this included two authors from the University of Sheffield's South-East European Research Centre in Greece, which is part of the International Faculty of the University of Sheffield.

Perhaps most significantly for the present study, eight articles were coauthored with practitioners. Seven of these authors were LIS practitioners, and in four cases the practitioners also had a clear connection to the iSchool, as either former or current students. One article was coauthored with a medical practitioner, working in emergency medicine (Ayatollahi, Bath, \& Goodacre, 2009), pointing to the potential value and implications of iSchool research for practice beyond LIS. For example, the article by Guillame and Bath (2008), based on content analysis of media coverage of a health scare about the safety of a vaccination program, makes recommendations that have significant practical implications for communicating public health issues or for media standards in reporting these issues. As shown in table 2, five articles had a health focus, and seven had a management dimension, but the most frequently occurring interdisciplinary connection was to education, with this link identified in eleven cases. These research studies may therefore have relevance for education practitioners and/or others working in education settings; in many examples, it was evident also that the research was connected with the authors' own roles as education practitioners/teachers, demonstrating another dimension of the link between research and practice in the iSchool.

Twelve articles acknowledged funding or other support from partner organizations. Four articles described projects funded by the U.K. Arts \& Humanities Research Council (Birdi, Wilson, \& Mansoor, 2012; Birdi, Wilson, \& Tso, 2009; Gorrell, Eaglestone, Ford, Holdridge, \& Madden, 2009; Gorrell, Ford, Eaglestone, Holdridge, \& Madden, 2011), and two articles acknowledged support from the University of Sheffield's Centre for Inquiry-based Learning in the Arts and Social Sciences (Cox, Levy, Stordy, \& Webber, 2008; Webber, 2010). Other funding organizations acknowledged include the European Union (Cox, Clough, \& Siersdorfer, 2011); the Joint Information Systems Committee of the U.K. higher-education funding councils (Levy, Aiyegabyo, \& Little, 2009); the U.K. Museums, Libraries and Archives Council (Wilson \& Corrall, 2008); Opening the Book Ltd., a library reader-development consultancy and training company (Birdi \& Syed, 2011); PriceWaterhouseCoopers (Polding, Nunes, \& Kingston, 2008); and the University's Centre for Health Information Management Research (Brewster \& Sen, 2011). While mainstream research funders, such as the Arts \& Humanities Research Council, feature prominently here, it is interesting also to note the range of connections with the world of educational and LIS practice. 


\section{Methods of Investigation and Strategies of Inquiry}

Many of the articles described research studies with complex designs or multiple studies carried out separately using different methods of data collection and analysis. This complexity and plurality make it difficult to summarize the methodologies used in the articles examined in terms of the conventional quantitative/qualitative dichotomy. Figure 2 summarizes the relative popularity of all research methods described in more than one article, revealing that interviews were the most frequently used method of investigation, followed by case studies. The case study category includes examination of published case studies, in addition to studies conducted in field settings; however, it should also be noted here that interviews actually formed part of the data collection process for many case studies.

Figure 3 shows the methods most frequently used for analysis of the data collected. Quantitative methods featured less frequently than qualitative methods within the articles sampled, but when they were used, they tended to be described more precisely.

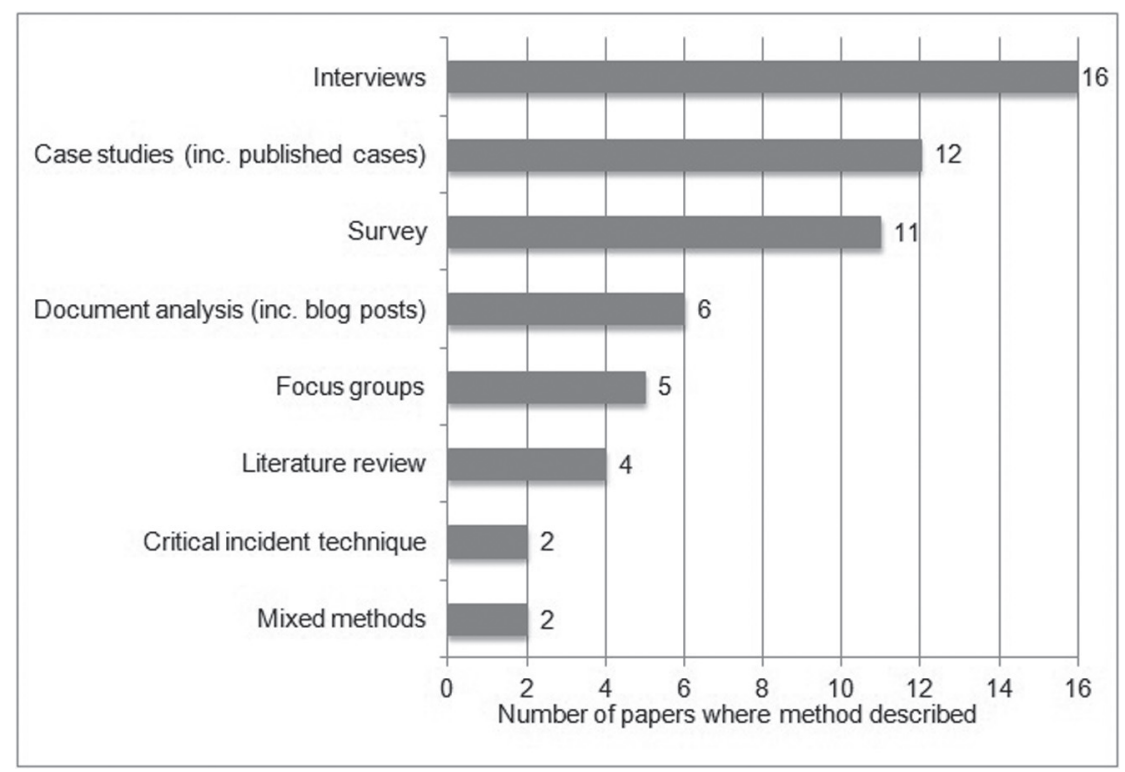

Figure 2. Research methods found in two or more papers. 


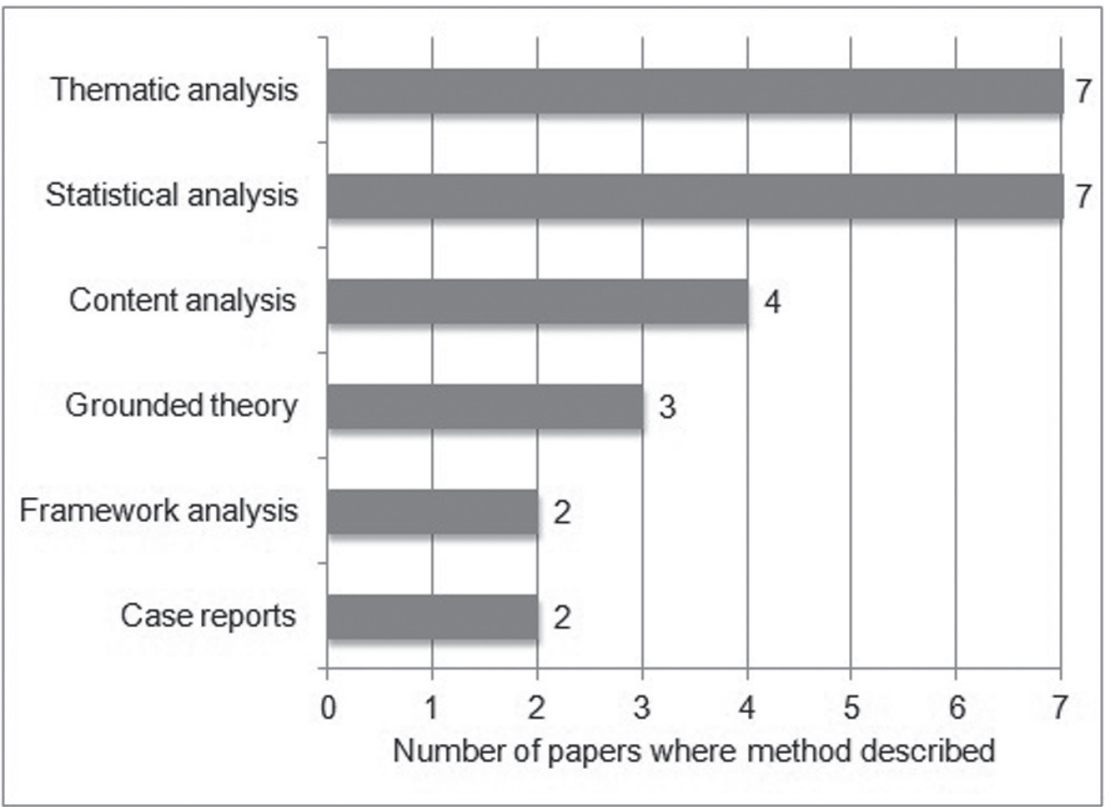

Figure 3. Data analysis methods found in papers.

Overall, seventeen articles appeared to describe primarily qualitative studies, while eight described explicitly quantitative studies. Only two articles used the phrase "mixed methods," although more articles actually included elements of mixing quantitative and qualitative approaches, in either the collection or the analysis of data. Four articles were dedicated to providing overviews of the literature in particular fields of study. Other methods or modes of inquiry described in individual articles again revealed both the versatility of iSchool researchers and a diversity of influences from other disciplines, as well as demonstrating methods particularly associated with the information field.

Examples of information science/studies/systems methods included citation searching (Bath, 2008); catalog searches (Tam et al., 2009); tracking controlled searches (Ford et al., 2009); developing a customized web crawler to examine the behavior of online communities (Cox et al., 2008); web site evaluation and preparation of patient information-seeking vignettes (Brewster \& Sen, 2010); and design research applied to prototyping and embedding a digital version of a print publication (Polding et al., 2008). The iSchool's strong links with the field of education were evident in the use (by members of the School's Education Informatics research group) of methodologies associated with that domain, namely a longitudinal cohort study of undergraduates (Levy \& Petrulis, 2012); use of 
guided reflections by distance learning master's students (Nazari \& Webber, 2011); a phenomenographic study of blended teaching and learning (Lameras et al., 2012); and an action research study (Webber, 2010). Finally, the use of a research workshop to discuss emerging findings and ideas for the remaining work with practitioners and other stakeholders (Birdi et al., 2009) shows how data gathering and research dissemination can be combined in a way that makes the research-practice connection clear and real for everyone involved.

\section{Audiences for Research and Relationships to Practice}

Eight articles described their intended audience in a direct and explicit way: seven include practitioners in their description, while one focuses specifically on doctoral researchers. Only eighteen articles (slightly less than half of the sample) specify the timeframe of the study, of which nine seem to have been published within one to two years of conducting the research.

Each article was also examined to determine its relationship to practice, with reference to the five criteria set out in table 1 (column 4), which are elaborated again here with examples:

- Motivation from practice to conduct the research, such as describing a framework developed "to support the growing interest in reflective practice within the library domain" (Sen \& Ford, 2009, p. 181)

- Practical or policy implications from the research, such as describing a study of next-generation OPACs showing "that the faceted browser, tag cloud, borrowing suggestions and relevance ranking are the most desirable and useful features from the perspective of international students" (Tam et al., 2009, p. 372)

- Specific strategies for transferring research into practice, such as "the findings have indicated that there is a promotional opportunity waiting to be taken by public library staff working with any minority ethnic community: . . . themed displays can be used to remove fears and prejudices in an entirely unobtrusive way, to present wider reading choices to all library users" (Birdi \& Syed, 2011, p. 829)

- Specific outputs for practitioners from the research, such as "the checklist presented in this article aims at supporting both practitioners and researchers in their risk thinking and assessment. For practitioners, the checklist is an important decision-making support tool and is aimed at helping in risk identification and assessment activities" (Zhou et al., 2008, p. 177)

- Implications for research arising from the work, including suggestions for future research or development of a theoretical framework, such as "the findings of this study can arguably provide a fresh understanding of how end-users interact with web-based resources and consequently can contribute to the theoretical framework of information seeking on the 
web. Moreover, the resulting conceptual framework is intended hopefully to be a useful reference point for researchers wishing to investigate user-based aspects of web searching" (Mansourian et al., 2008, p. 415)

Figure 4 summarizes the relationships to practice found in the articles examined. Although the evaluation of the characteristics was quite subjective and some elements overlap, the criteria suggested here identify dimensions that serve as a starting point for assessing the relationship of research studies to practice in the field.

All the articles provided some indication of the practical or policy implications of the research, and almost all appeared to indicate a motivation for the research originating in practice. Fifteen articles (40.5 percent of the sample) appeared to display all these characteristics, suggesting that they may represent good examples of connecting research with practice. Among the most explicit examples of relating research to practice were two articles that dealt with the practice of research (Gorrell et al., 2011; Idrees et al., 2011) and four articles dealing in whole or in part with the practice of education (Corrall, 2010; Levy et al., 2009; Sen \& Ford, 2009; Webber, 2010). This may suggest that direct statements linking research to practice can be most clearly discerned in studies that emerge directly from the current practice context of the authors themselves, either as researchers or as educators.

\section{Types and Numbers of Items Referenced}

Data relating to the composition of each article's reference list were recorded, including the numbers of entries for different types of material.

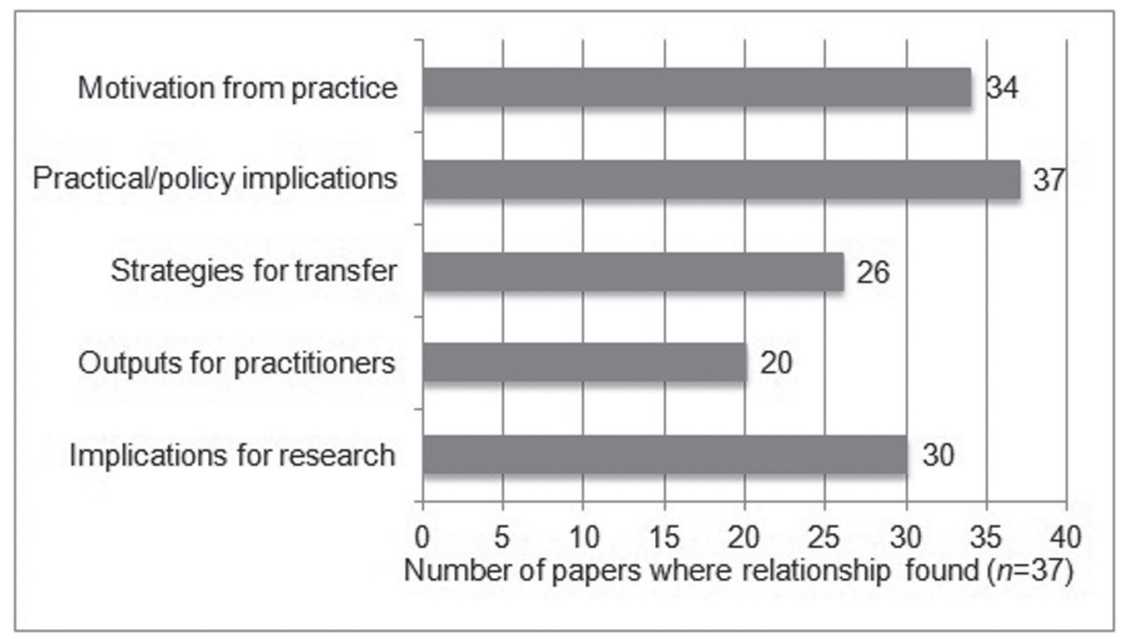

Figure 4. Statements relating research to practice. 
For example, twelve articles cited Sheffield iSchool dissertations. Seven of these articles were based all or in part on studies conducted for a dissertation or thesis written by one of the article authors; two of these seven articles also included citations to two additional iSchool dissertations, cited as additional relevant work. There were therefore sixteen such citations in total: one citation of an undergraduate dissertation, eleven citations of master's dissertations, and four citations of doctoral theses.

The reference list data also present the opportunity to examine patterns of referencing in different articles. As shown in table 2, Ford's (2008) contribution to the Annual Review of Information Science and Technology contained the largest number of references (116) and was in that sense the most extensively referenced article; however, it was also the longest article, with a recorded word count of 16,670. Examining the number of references alongside the word count and dividing the number of words recorded by the number of references listed provided a words-per-reference figure. While acknowledging our earlier caveats about the imperfect nature of the word counts recorded for the present sample, the words-per-reference figure is arguably more interesting than the references-per-article figure here, as it can serve as an indicator of the density of referencing in an article. Figure 5 summarizes the results of this calculation for the sample.

The analysis revealed that Corrall's (2010) article in Library Management was the most densely referenced, with one reference for every eighty-nine words (compared with one reference per 144 words for Ford's article). Conversely, the least densely referenced article is Cox et al. (2008), with one reference for every 542 words. The latter article was published in ITAL$I C S$, a U.K. journal for learning and teaching practitioners in information

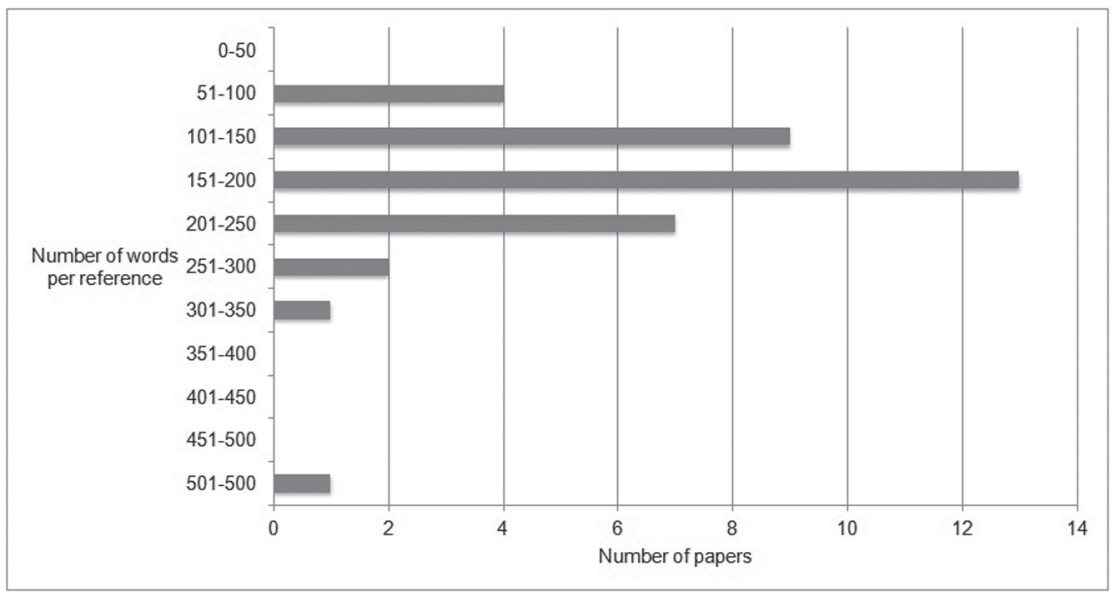

Figure 5. Density of referencing in papers sampled. 
and computer sciences in higher education, and may be interpreted as illustrating the different style adopted when writing for a practitioner audience.

The ITALICS article also has the lowest proportion of journal articles in its reference list, with only one journal article included among twelve references (which are otherwise a mix of books and web-based articles), compared to Bath (2008), in which journal articles account for fifty-eight (87.9 percent) of the sixty-six items in the reference list. Figure 6 shows journal article references as percentages of the total references for each article examined, revealing that the dominant pattern here was for journal articles to account for around half (41 to 60 percent) of the total number of references, which occurred in twenty of the thirty-seven articles (54 percent).

The number of references in each article including URLs was also examined, revealing that three articles provided no URLs, while three (Cox et al., 2008; Tam et al., 2009; Webber, 2010) included URLs for 50 percent or more of their reference list. Figure 7 shows that the proportion of references with URLs was relatively low across the sample.

\section{Discussion}

The focus group discussions explored a wide variety of factors that motivate people to conduct research. A number of participants told the stories of their personal journeys to become researchers, often developing from their experiences as practitioners. In contrast, the motivations described

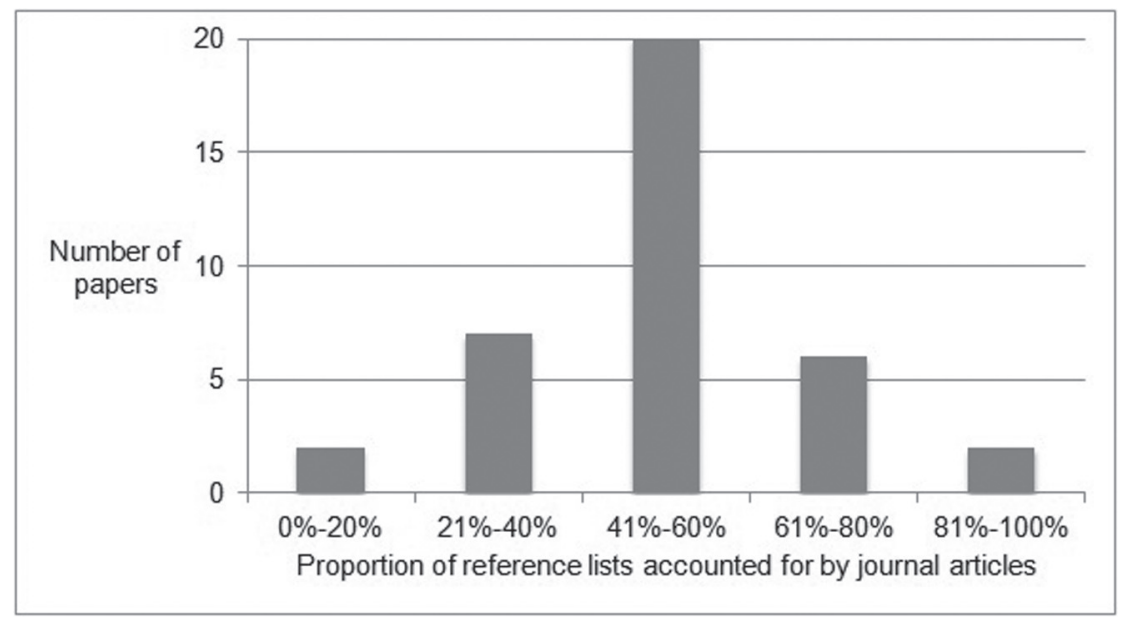

Figure 6. Proportion of journal articles in reference lists. 


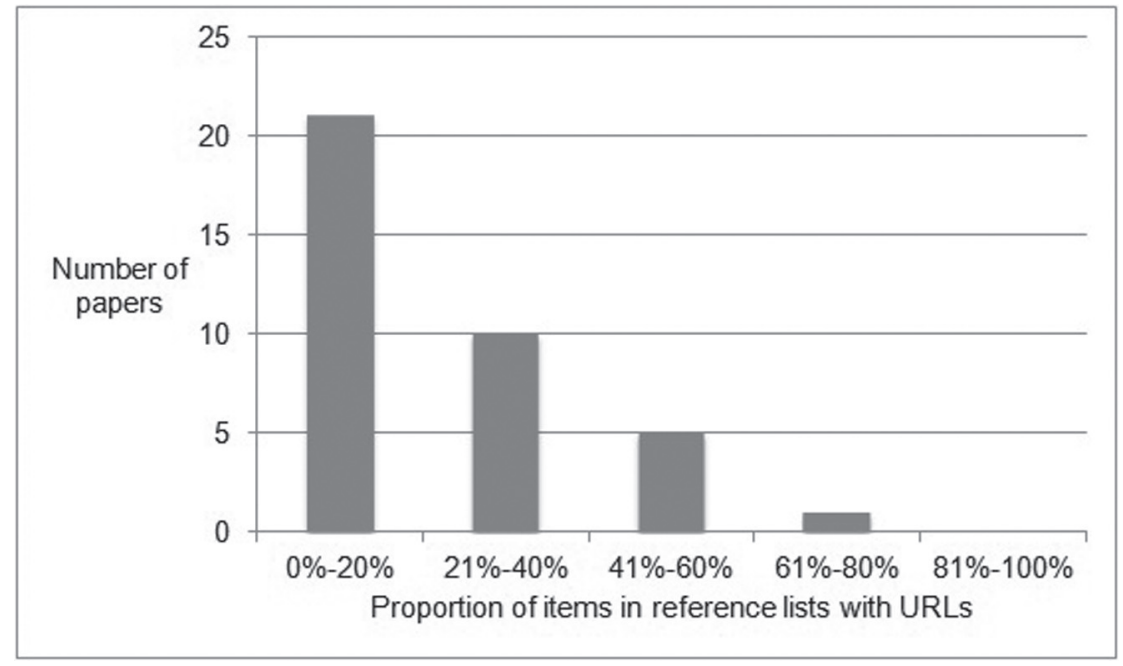

Figure 7. Proportion of references with URLs.

in the articles analyzed here were generally presented in more impersonal terms, although most made some reference to motivation from practice.

The prominence of articles with an interdisciplinary aspect relating to education reinforces the suggestion from the focus groups of the importance of the role of researcher-as-teacher. The process of educating new professionals presents a significant, although difficult to evaluate, opportunity for research to impact on practice, which was followed through in several cases in the coauthoring of articles by faculty with their former students.

The focus groups and the content analysis also highlight the distinction between communication or dissemination of research and formally recognized research impact (of the type defined and accepted by the U.K. REF). Although such impacts require research to be communicated, it seems quite possible to communicate and disseminate research without any impact being officially acknowledged. As Haddow and Klobas (2004, p. 37) note, "There is little communication of research to practice through periodical publications," a point raised by focus group members, who also discussed whether social media might be an effective way of communicating more directly with practitioners.

Both the focus groups and the content analysis also explored different dimensions of "practice" in the iSchool context. Most researchers and faculty in the library and information management research area retain a strong sense of their identity as librarians or information professionals, 
which underpinned not only their motives for doing research but also their conceptions of the impact of research and thoughts about its dissemination, shown in their use of web-based communication and professional networks. Additionally, most of the research subjects were engaged in the practice of teaching and, indeed, the practice of research itself, and these academic communities formed another category of practitioner audiences for some of the research undertaken. Research by iSchool members covers a remarkably wide range of practice settings from public libraries to hospital departments and university settings and from business and industry to "serious leisure" activities, such as food blogging (Cox \& Blake, 2011).

The research can also be set in the context of the eleven gaps between researchers and practitioners in library and information science identified by Haddow and Klobas (2004, p. 31). Four gaps were identified primarily with practitioners:

- Motivation gap: Practitioners are not interested in research.

- Activity gap: Few practitioners conduct research.

- Education gap: Practitioners do not have the knowledge and skill to conduct research.

- Temporal gap: Practitioners do not have time to read or conduct research.

The present study did not collect data from current LIS practitioners and therefore did not gather conclusive evidence on these practitioner gaps, but the research provided some insights into the issues identified here. First, on motivation, the focus group participants were almost all former LIS practitioners who were interested in research but chose to migrate to the academy to pursue their interests at a level beyond what they could do in practice settings. Second, on activity, evidence was provided from the focus groups and content analysis of former iSchool students who continued to conduct and/or disseminate research after graduation. Third, on education, the Sheffield master's curriculum, which requires all students to take a research methods course and undertake a dissertation project, is arguably a positive factor contributing to the continuing activity and interest in research of iSchool graduates. Fourth, on time to read, the length of many of the articles examined here is arguably a negative factor contributing to the temporal gap.

Other gaps identified by Haddow and Klobas (2004) are more directly concerned with facets of the research-practice relationship that are evident in our analysis. For example, publishing in more practitioner-orientated journals—such as Aslib Proceedings (Birdi, 2011; Chen et al., 2011; Cox \& Blake, 2011; Gumulak \& Webber, 2011; Idrees et al., 2011); Health Information and Libraries Journal (Brewster \& Sen, 2010); Journal of Librarianship and Information Science (Birdi et al., 2009, 2012; Polding et al., 2008); 
Program (Mansourian et al., 2008; Tam et al., 2009); and Library Management (Corrall, 2010; Vasconcelos, 2008; Wilson \& Corrall, 2008)-may contribute to closing the "knowledge gap," where "researchers and practitioners would be more informed if there were more effective communication between them" (Haddow \& Klobas, 2004, p. 31).

Citing web-based material, such as reports and other documents from professional bodies, connects research with familiar practitioner reference points, indicates that researchers $d o$ read practitioners' literature, and can contribute to closing their "reading gap." Involving practitioners as coauthors suggests a level of mutual understanding and respect that challenges the perceived "culture gap" and also helps to close the "publication gap" arising from the identified dearth of research publication by practitioners (Haddow \& Klobas, 2004, p. 32; Hall, 2010, p. 84). In addition, our faculty focus group highlighted the need to "translate . . because the language of a researcher can be very different to a practitioner language" (FM5), pointing to an ability and willingness to close the "terminology gap."

An evident failure in our sample to specify the timeframes of empirical studies and/or publish the findings quickly risks perpetuating Haddow and Klobas's (2004, p. 32) "immediacy gap," which could be partially resolved by adopting the practice described in the early-career researcher focus group of disseminating findings in practitioner periodicals (which generally have shorter publication cycles than academic journals) or via professional association web sites, in advance of publishing them in peerreviewed journals. Our study did not specifically investigate Haddow and Klobas's (2004, p. 31) "relevance gap," which would merit further research with practitioners to examine "what constitutes a 'problem' worth investigating in practice and research."

\section{Conclusion And Recommendations}

The present study has investigated perspectives and practices of doctoral researchers and faculty members on the relationship between research and practice in librarianship and information management. The research has acknowledged limitations, including small sample sizes and investigator subjectivity in interpreting the data collected. However, it breaks new ground in its combined use of focus groups and content analysis to explore research-practice relationships and its particular focus on contemporary iSchool practice. The study has contributed fresh insights to current discussion about strategies for connecting research with practice and offers specific suggestions aimed at strengthening these vital connections.

The focus groups explored individuals' motivations for undertaking research and their personal journeys to become researchers. Some felt that research was one way of expressing their identity as library or information professionals and contributing to their profession. Others were particularly motivated by a sense of research as a vocation and a desire to con- 
tribute to the development of new knowledge. The groups also discussed their perceptions of the impact achieved by research, in the context of criteria used for institutional evaluation, impact accomplished through teaching activities, and impact gained via personal contacts. Participants also discussed methods of disseminating research findings to practitioners, suggesting a growing role for social media. Content analysis of thirtyseven published articles showed how the relationship between research and practice is reflected in the publications of iSchool faculty, particularly in collaborations and partnerships with LIS practitioners, in selection of venues for publication and choice of material for referencing, and, most notably, through five types of statements in the articles explicitly relating the research to practice.

The following recommendations for conducting and communicating academic research in LIS are intended to strengthen the relationship between research and practice:

- Collaborate with practitioners on research topics of interest to them.

- Involve students and alumni in research projects and assist them in publishing their work.

- Conduct a longitudinal study of alumni engagement with research in practice settings.

- Specify practitioners as a target audience for articles that describe research intended to have an impact on practice.

- Clearly state the timeframe of research studies so that practitioners and others can evaluate its relevance to current problems and situations.

- Describe research methods and analysis procedures in a clear and accessible way and include copies of data collection instruments to encourage their use in local contexts.

- Make explicit any practical project outputs for practitioners when describing the project in journal articles.

- Make use of open-access publication opportunities.

- Communicate research in the most appropriate way to reach practitioners, including through practitioner periodicals, professional associations, and social media.

- Use metrics associated with social media to provide additional indicators of impact (e.g., blog page views).

Finally, one specific suggestion for future research is to explore the issues identified in the present study with LIS practitioners, including, in particular, investigating their perspectives on the motivation, relevance, and education gaps identified in the literature. 


\section{ACKNOWLEDGMENTS}

The authors would like to thank Dr. Yazdan Mansourian for formulating the initial proposal and original design for the research. They are also indebted to all the researchers at the University of Sheffield Information School who participated in the investigation and/or contributed through their publications to the insights gained in the study.

\section{REFERENGES}

ASLIB: Association for Information Management (2012). ASLIB Journals. Bingley, England: ASLIB. Retrieved October 9, 2012, from http://www.aslib.co.uk/resources/journals_intro .htm

Ali, S. N. (1985). Library science research: Some results of its dissemination and utilization. Libri 35, 151-162.

Ayatollahi, H., Bath, P. A., \& Goodacre, S. (2009). Paper-based versus computer-based records in the emergency department: Staff preferences, expectations, and concerns. Health Informatics Journal, 15, 199-211.

Bath, P. A. (2008). Health informatics: Current issues and challenges. Journal of Information Science, 34, 501-518.

Berg, S. A., Hoffmann, K., \& Dawson, D. (2009). Integrating research into LIS field experiences in academic libraries. Journal of Academic Librarianship, 35, 591-598.

Birdi, B. (2011). Investigating fiction reader characteristics using personal construct theory. Aslib Proceedings, 63, 275-294.

Birdi, B., \& Syed, M. (2011). Exploring reader response to minority ethnic fiction. Library Review, 60, 816-831.

Birdi, B., Wilson, K., \& Mansoor, S. (2012). "What we should strive for is Britishness": An attitudinal investigation of ethnic diversity and the public library. Journal of Librarianship and Information Science, 44, 118-128.

Birdi, B., Wilson, K., \& Tso, H. M. (2009). The nature and role of empathy in public librarianship. Journal of Librarianship and Information Science, 41, 81-89.

Booth, A. (2003). Bridging the research-practice gap? The role of evidence based librarianship. New Review of Information and Library Research, 9, 3-23.

Brewster, L., \& Sen, B. (2010). Quality signposting: The role of online information prescription in providing patient information. Health Information and Libraries Journal, 28, 59-67.

Brown, D., \& Sen, B. (2010). The undergraduate prospectus as a marketing tool for academic libraries. New Review of Academic Librarianship, 16, 160-191.

Bryman, A. (2004) Social research methods (2nd ed.). Oxford, England: Oxford University Press.

Busha, C. H., \& Harter, S. P. (1980). Research methods in librarianship: Techniques and interpretation. New York: Academic Press.

Chartered Institute of Library and Information Professionals (CILIP). (2012). Sage journals. London: CILIP. Retrieved October 9, 2012, from http://www.cilip.org.uk/membership/ benefits/informed/online-databases/Pages/sage.aspx

Chen, H., Nunes, J. M. B., Zhou, L., \& Peng, G. C. (2011) . Expanding the concept of requirements traceability: The role of electronic records management in gathering evidence of crucial communications and negotiations. Aslib Proceedings, 63, 168-187.

Childs, S., \& Dobbins, S. (2003). The research-practice spiral. VINE, 33, 51-64.

Clapton, J. (2010). Library and information science practitioners writing for publication: Motivations, barriers and supports. Library and Information Research, 34(106). Retrieved October 23, 2012, from http://www.lirgjournal.org.uk/lir/ojs/index.php/lir/article/view/217/287

Corrall, S. (2008). Information literacy strategy development in higher education: An exploratory study. International Journal of Information Management, 28, 26-37.

Corrall, S. (2010). Educating the academic librarian as a blended professional: A review and case study. Library Management, 31, 567-593.

Corrall, S., \& Sriborisutsakul, S. (2010). Evaluating intellectual assets in university libraries: A multi-site case study from Thailand. Journal of Information and Knowledge Management, 9, 277-290. 
Cox, A. M. (2008). An exploration of concepts of community through a case study of UK university web production. Journal of Information Science, 34, 327-345.

Cox, A. M., \& Blake, M. K. (2011). Information and food blogging as serious leisure. Aslib Proceedings, 63, 204-220.

Cox, A. M., Clough, P., \& Siersdorfer, S. (2011). Developing metrics to characterize Flickr groups. Journal of the American Society for Information Science and Technology, 62, 493-506.

Cox, A. M., Levy, P., Stordy, P., \& Webber, S. (2008). Inquiry-based learning in the first-year information management curriculum. ITALICS, 7(1). Retrieved October 10, 2012, from http://www.ics.heacademy.ac.uk/italics/vol7iss1/pdf/Paper1.pdf

Fisher, W. (1999). When write is wrong: Is all our professional literature on the same page? Library Collections, Acquisitions, E Technical Services, 23, 61-72.

Ford, N. (2008). Educational informatics. Annual Review of Information Science and Technology, 42, 497-544.

Ford, N., Eaglestone, B., Madden, A., \& Whittle, M. (2009). Web searching by the "general public": An individual differences perspective. Journal of Documentation, 65, 632-667.

Gorrell, G., Eaglestone, B., Ford, N., Holdridge, P., \& Madden, A. (2009). Towards "metacognitively aware" IR systems: An initial user study. Journal of Documentation, 65, 446-469.

Gorrell, G., Ford, N., Eaglestone, B., Holdridge, P., \& Madden, A. (2011). Countering method bias in questionnaire-based user studies about metacognition. Journal of Documentation, 67, 507-524.

Goulding, A., \& Matthews, G. (2002). Putting research into practice. Journal of Librarianship and Information Science, 34, 63-65.

Goulding, A., \& Usherwood, B. (2003). Research-led teaching in librarianship and information studies. Journal of Librarianship and Information Science, 35, 137-139.

Guillame, L., \& Bath, P. A. (2008). A content analysis of mass media sources in relation to the MMR vaccine scare. Health Informatics Journal, 14, 323-334.

Gumulak, S., \& Webber, S. (2011). Playing video games: Learning and information literacy. Aslib Proceedings, 63, 241-255.

Haddow, G. (2010). Communicating research to practice: The role of professional association publications. Library and Information Research, 34(108), 33-44. Retrieved October 23, 2012, from http://www.lirgjournal.org.uk/lir/ojs/index.php/lir/article/view/332/489

Haddow, G., \& Klobas, J. E. (2004). Communication of research to practice in library and information science: Closing the gap. Library $\mathcal{E}^{2}$ Information Science Research, 26, 29-43.

Hall, H. (2010). Promoting the priorities of practitioner research engagement. Journal of Librarianship and Information Science, 42, 83-88.

Hall, H., Kenna, S., \& Oppenheim, C. (2011). The rationale for the DREaM: Developing Research Excellence and Methods Project. Library and Information Research, 35(110), 4349. Retrieved October 8, 2012, from http://www.lirgjournal.org.uk/lir/ojs/index.php/ $\mathrm{lir} /$ article/download/475/516

Hildreth, C. R., \& Aytac, S. (2007). Recent library practitioner research: A methodological analysis and critique. Journal of Education for Library $\mathcal{E}^{2}$ Information Science, 48, 236-258.

Idrees, I., Vasconcelos, A. C., \& Cox, A. (2011). The use of grounded theory in PhD research in knowledge management: A model four stage research design. Aslib Proceedings, 63, 188-203.

Klobas, J. E., \& Clyde, L. A. (2010). Beliefs, attitudes and perceptions about research and practice in a professional field. Library and Information Science Research, 32, 237-245.

Kloda, L. A., Koufogiannakis, D., \& Mallan, K. (2011). Transferring evidence into practice: What evidence summaries of library and information studies research tell practitioners. Information Research, 16(1). Retrieved October 23, 2012, from http://informationr.net/ ir/16-1/paper465.html

Koufogiannakis, D., Slater, L., \& Crumley, E. (2004). A content analysis of librarianship research. Journal of Information Science, 30, 227-239.

Lameras, P., Levy, P., Paraskakis, I., \& Webber, S. (2012). Blended university teaching using virtual learning environments: Conceptions and approaches. Instructional Science, 40, 141-157.

Lang, M. (2002). On the dissemination of I.S. research findings into practice. Proceedings of the Informing Science + IT Education Conference, June 19-21, 2002, Cork, Ireland. Retrieved October 23, 2012, from http://informingscience.org/proceedings/IS2002Proceedings/ papers/Lang102OnThe.pdf 
Levy, P., \& Petrulis, R. (2012). How do first-year university students experience inquiry and research, and what are the implications for the practice of inquiry-based learning? Studies in Higher Education, 37, 85-101.

Levy, P., Aiyegabyo, O., \& Little, S. (2009). Designing for inquiry-based learning with the Learning Activity Management System. Journal of Computer-Assisted Learning, 25, 238-251.

Luo, L. (2011). Fusing research into practice: The role of research methods education. Library E Information Science Research, 33, 191-201.

MacDonald, J., Bath, P., \& Booth, A. (2011). Information overload and information poverty: Challenges for healthcare services managers? Journal of Documentation, 67, 238-263.

Mansourian, Y., Ford, N., Webber, S., \& Madden, A. (2008). An integrative model of "information visibility" and "information seeking" on the web. Program, 42, 402-417.

McClure, C. R. (1989). Increasing the usefulness of research for library managers: Propositions, issues, and strategies. Library Trends, 38, 280-294. Retrieved October 24, 2012, from https://www.ideals.illinois.edu/handle/2142/7658

McKechnie, L. (E. F.), Julien, H., \& Oliphant, T. (2008). Communicating research findings to library and information science practitioners: A study of ISIC papers from 1996 to 2000. Information Research, 13(4). Retrieved October 23, 2012, from http://informationr.net/ ir/13-4/paper375.html

McKee, B. (2007). Research into practice: Prospects for a future framework. Library and Information Research, 31(97), 25-32. Retrieved 23 October, 2012 from http://www.lirgjournal .org.uk/lir/ojs/index.php/lir/article/download/22/5

McPherson, M. A., \& Nunes, J. M. (2008). Critical issues for e-learning delivery: What may seem obvious is not always put into practice. Journal of Computer Assisted Learning, 24, 433-445.

Montanelli, D. S., \& Mak, C. (1988). Library practitioners' use of library literature. Library Trends, 36, 765-783. Retrieved October 24, 2012, from https://www.ideals.illinois.edu/ handle/2142/7567

Nazari, M., \& Webber, S. (2011). What do the conceptions of geo/spatial information tell us about information literacy? Journal of Documentation, 67, 334-354.

Polding, R., Nunes, J. M. B., \& Kingston, B. (2008). Assessing e-book model sustainability. Journal of Librarianship and Information Science, 40, 255-268.

Powell, R. R., \& Connaway, L. S. (2004). Basic research methods for librarians (4th ed.). Westport, CT: Libraries Unlimited.

Powell, R. R., Baker, L. M., \& Mika, J. J. (2002). Library and information science practitioners and research. Library and Information Science Research, 24, 49-72.

Research Excellence Framework (REF). (2012). Panel criteria and working methods. Retrieved October 24, 2012, from http://www.ref.ac.uk/media/ref/content/pub/panelcriteriaand workingmethods/01_12.pdf

Robbins, J. B. (1990). Research in information service practice. Library and Information Science Research 12, 127-128.

Saracevic, T., \& Perk, L. J. (1973). Ascertaining activities in a subject area through bibliometric analysis: Application to library literature. Journal of the American Society for Information Science, 24, 120-134.

Schlögl, C., \& Stock, W. G. (2008). Practitioners and academics as authors and readers: The case of LIS journals. Journal of Documentation, 64, 643-666.

Sen, B., \& Ford, N. (2009). Developing reflective practice in LIS education: The SEA-change model of reflection. Education for Information, 27, 181-195. Preprint retrieved October 7, 2012, from http://eprints.whiterose.ac.uk/42933

Swigger, K. (1985). Institutional affiliations of authors of research articles. Journal of Education for Library and Information Science, 26, 105-109.

Tam, W., Cox, A. M., \& Bussey, A. (2009). Student user preferences for features of next generation OPACs: A case study of University of Sheffield international students. Program, 4, 349-374.

Taylor \& Francis (2012). Studies in Higher Education. Retrieved October 9, 2012, from http:// www.tandfonline.com/toc/cshe20/current

Turner, K. J. (2002). The use of applied library and information studies (LIS) research in New Zealand libraries. Library Review, 51, 230-240.

University of Sheffield. (2012). The university's mission. Retrieved October 24, 2012, from http://www.shef.ac.uk/strategicplan/mvi/mission 


\section{LIBRARY TRENDS/WINTER 2013}

Usherwood, B. (2002). Accounting for outcomes: Demonstrating the impact of public libraries. Australasian Public Libraries and Information Services, 15, 5-13.

Vasconcelos, A. C. (2008). Dilemmas in knowledge management. Library Management, 29, $422-443$.

Webber, S. (2010). Investigating modes of student inquiry in Second Life as part of a blended approach. International Journal of Virtual and Personal Learning Environments, 1(3), 55-70. Preprint retrieved October 7, 2012, from http://dis.shef.ac.uk/sheila/ijvple-webber.pdf

White, M. D., \& Marsh, E. E. (2006). Content analysis: A flexible methodology. Library Trends, 55, 22-45. Retrieved October 10, 2012, from https://www.ideals.illinois.edu/ handle/2142/3670

White Rose Research Online. (2011). About White Rose Research Online. Retrieved October 24, 2012, from http://eprints.whiterose.ac.uk/docs/information.html

Wiley. (2012). Journal of the American Society for Information Science and Technology. Hoboken: Wiley. Retrieved October 9, 2012, from http://onlinelibrary.wiley.com/journal/10.1002/ (ISSN) 1532-2890/homepage/ProductInformation.html

Wilson, K., \& Corrall, S. (2008). Developing public library managers as leaders: Evaluation of a national leadership development programme. Library Management, 29, 473-488.

Zhou, L., Vasconcelos, A. C., \& Nunes, J. M. (2008). Supporting decision making in risk management through an evidence-based information systems project risk checklist. Information Management and Computer Security, 16, 166-186.

Angharad Roberts is a PhD researcher at the University of Sheffield Information School. She has previously worked for academic libraries in the United Kingdom, including Anglia Ruskin University Library, Chelmsford, and Imperial College London Library Service. She obtained an MA in Library and Information Studies from University College London in 2008, where she was awarded a Cowley Prize, and she became a chartered member of the U.K. Chartered Institute of Library and Information Professionals (CILIP) in 2010.

Andrew D. Madden has worked as a research associate in the University of Sheffield's Information School since 2001, where he has been investigating various aspects of Internet searching. He has been involved in educating students ranging in age from 11 to 80 and has published several articles on Internet seeking and educational informatics. He has a BSc in biology and mathematics, a PhD in agricultural botany, and an MSc in information management.

Sheila Corrall is professor and chair of the Library and Information Science Program in the School of Information Sciences at the University of Pittsburgh, where she teaches courses on research methods and academic libraries. Her research interests include the application of business management concepts to library and information services; evolving roles and competencies of library and information workers; and strategic development of information literacy. She worked at the University of Sheffield Information School from 2004 to 2012 and was head of the iSchool for four years. She previously worked in public, special, national, and academic libraries, including ten years in professional and management roles at The British Library and thirteen years as director of library, information, and academic services at three universities in the United Kingdom. She is a former president of the Chartered Institute of Library and Information Professionals (CILIP) and currently serves on the editorial boards of five international journals. 